\title{
Potency of Radical Scavenging Activity and Determination of Total Phenolic Content of Five Ethanolic Extract of Rhizome Zingiberaceae Family
}

\author{
Muhammad Da'i", Didiek Setiawan, Rosita Melannisa
}

\author{
Faculty of Pharmacy, Universitas Muhammadiyah Surakarta, Jalan Achmad Yani, Sukoharjo, Indonesia
}

\begin{abstract}
Several studies show that some plants and fruits could protect human body from free radical danger exposure. Zingiberaceae family has some chemical substances that have antiradical activity, such as phenolic compound and flavonoid. The aim of this study is to determine the correlation of total phenolic compound towards its antiradical activity. Antiradical activity assay was determined by DPPH method (I,I difenil-2-pikrilhidrazil). The total phenolic compound is determined by spectrofotometry using Folin-Ciocalteu reagent and counted as GAE (Gallic Acid Equivalent). Based on this study, the total phenolic concentration of ethanolic extract of jahe (Zingiber officinale (L.) Rosc), kencur (Kaemferia galanga L.), lengkuas (Languas galanga), lempuyang gajah (Zingiber littorale) and lempuyang pahit (Zingiber americana) is $73.99 \mathrm{mg} / \mathrm{g} ; 23.848 \mathrm{mg} / \mathrm{g} ; 37.84 \mathrm{I} \mathrm{mg/g;} 49.725 \mathrm{mg} / \mathrm{g}$ and 40.802 $\mathrm{mg} / \mathrm{g}$ respectively. The radical scavenging activity $\left(\mathrm{IC}_{50}\right)$ of jahe $(27.38 \mu \mathrm{g} / \mathrm{mL})$, lengkuas $(93,27$ $\mu \mathrm{g} / \mathrm{mL})$, lempuyang pahit $(105,08 \mu \mathrm{g} / \mathrm{mL})$, meanwhile lempuyang gajah and kencur show low activity of radical scavenging.
\end{abstract}

Keywords: Zingiberaceae, total phenolic compound, antiradical, DPPH

\section{INTRODUCTION}

Free radical is an atom or atomic group having one or more uncoupled electron (Fessenden and Fessenden, 1986). Free radical in human body is very reactive and can interact with some parts of body or cells. This condition can happen continuesly and causing the damage to the human tissue. Approximately as many as 40 diseases including atherosclerosis, hypertention, ischemy, alzheimer, parkinson, cancer, and the inflamation can be caused by free radical damage (Niki, et al., 1995; Khanom, et al., 2000; Tripathy, et al., 2001; Toda, et al., 1991; Behera, et al., 2004).

Antioxidant is needed in order to inhibit the free radical activity. Some antioxidant compounds contained in plants and fruits such ascaroten, flavonoid, and others phenolic compounds (Teow, et al., 2006). Other compound such as vitamin $\mathrm{C}$ and $\mathrm{E}$ (Windono, 2001) showed some benefits in the body protection of free radical (Rohman and Riyanto, 2006).

Family of Zingiberaceae is known as antioxidant source. The member of
Zingiberaceae family such as jahe (Zingiber officinale (L.) Rosc), kencur (Kaemferia galanga L.), lengkuas (Languas galanga), lempuyang gajah (Zingiber littorale), and lempuyang pahit (Zingiber americana) have been used in traditional medication. Jahe (Zingiber officinale (L.) Rosc) has been reported to have antioxidant, anticancer, antiinflamation, antiangiogenesis, antiartherosclotic, and inhibition ability towards carsinogenic agents (Shukla, 2007; Surh, 2003; Kim, 2004; Shafina, 2008). Kencur (Kaemferia galanga L.) extract has antibactery (Tewtrakul, et al., 1983), anticancer, antihipertensi, larvasidal activity and can also be used as skin disease therapy, rheumatic, and mellitus diabetic (Tara, et al., 2006).

Lengkuas (Languas galanga L.) contain 1'-acetoxychavicolacetate (ACA) and 1'acetoxyeugenolacetate as antitumor compound (Zaeoung, et al., 2004). Lempuyang gajah (Zingiber littorale) repoted to have antiulcer, antioxidant, antimicrobia (Bhuiyan, et al., 2009), antitumor and antiinflamation (Murakmi, et al., 2002; Sakinah, et al., 2007; Abdul, et al., 2008). Some compounds 
contained in Zingiberaceae family are phenolic substances such as gingerol, shogaol, gingeron (Ravindran, et al., 2005), bidescurcuminoid (Wulandari, 1996), kaempferol (Usia, et al., 2004), flavonoid, terpenoid and non polar constituents such as curcuminoid, kava piron and gingerol (Sirat, et al., 1996). Those substances have been known to have antiradical (Sirat, et al., 1996). The study about the comparation of radical scavenging activity Zingiberaceae (jahe, kencur, lengkuas, lempuyang gajah and lempuyang pahit) and the concentration of total phenolic constituent that probably responsible as antiradical compound needs to be done and to be further analyzed in the correlation between phenolic compound concentration and the radical scavenging activity by DPPH method.

\section{MATERIALS AND METHODS}

\section{Materials}

Five ethanolic extracts from jahe (Zingiber officinale (L.) Rosc), kencur (Kaemferia galanga L.), lengkuas (Languas galanga), lempuyang gajah (Zingiber zerumbet) and lempuyang pahit (Zingiber americana) were obtained from Faculty of Pharmacy Universitas Muhammadiyah Surakarta, DPPH (2,2-diphenyl-1-picrylhydrazyl), etanol p.a, technical ethanol, aqua bidestilata, vitamin $\mathrm{E}$, asam galat, Folin Ciocalteau reagent, $\mathrm{Na}_{2} \mathrm{CO}_{3}$, alumunium foil, TLC plates.

\section{Determination of Total Phenolic Concentration}

Based on the modified method from Chun, et al. (2003), the determination of total phenolic compound of the extract was done by Folin Ciocalteau method with Galic acid as the reference. The value obtained was the equivalence of miligram of galic acid per gram of extract Gallic Acid Equivalent (GAE).

\section{Antioxidant Activity Assay (DPPH method)}

Sample from the stock solution of ethanolic extract from jahe (Zingiber officinale (L.) Rosc), kencur (Kaemferia galanga L.), lengkuas (Languas galanga), lempuyang gajah (Zingiber zerumbet), lempuyang pahit (Zingiber americana) and vitamin $\mathrm{E}$ were prepared in five different concentrations. Sampel added by 0.7 $\mathrm{mL}$ DPPH $0.4 \mathrm{mM}$ and ethanol added up to 5.0 $\mathrm{mL}$. This mixture was homogenized by mxing for 30 seconds and incubated for 30 minutes.

The sampel absorbance were measured by UV-Vis spectrofotometer (Shimadzu) with $\lambda_{\max } 517.6 \mathrm{~nm}$. The sample absorbance also compared with the control solution containing $0.7 \mathrm{~mL}$ DPPH $0.4 \mathrm{mM}$ diluted in ethanol. The percentage $(\%)$ of antiradical activity were measured. The linier regretion between concentration curve versus antiradical activity precentage were obtained. Then, the linier regretion formula and sample concentration at $50 \%$ activity were determined.

\section{RESULT AND DISCUSSION}

\section{Total Phenolic Concentration}

Total phenolic concentration was determined by using Folin-Ciocalteu reagent. The mechanism of this reagent is based on the hydroxy-fenolic group's reducting ability. The existence of aromatic groups in phenolic compounds (hydroxy phenolic groups) can turn phosphomolybdate and phosphotungstate into molybdenum which have blue colour (Sudjadi and Rohman, 2004).

The total phenolic concentration of rhizomes ethanolic extract from the highest to the lowest are jahe $(73.992 \mathrm{mg} / \mathrm{g})$, lempuyang gajah (49.725 mg/g), lempuyang pahit (40.802 $\mathrm{mg} / \mathrm{g})$, lengkuas (37.841 $\mathrm{mg} / \mathrm{g}$ ) and kencur (23.848 mg/g) (Fig. 1). 


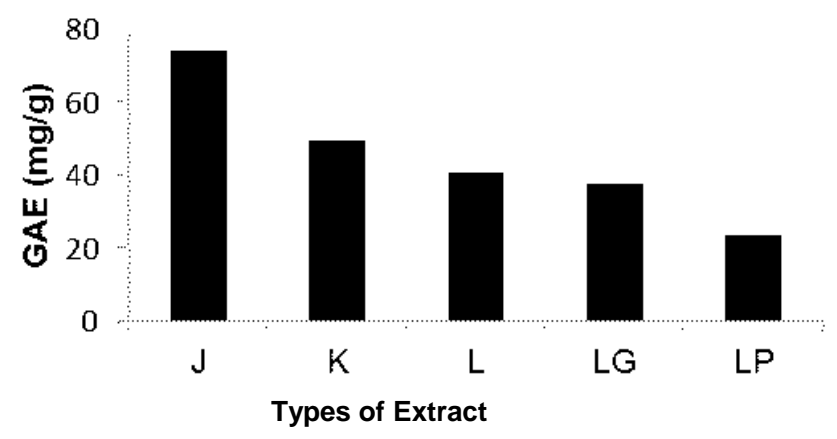

Figure I. Total phenolic concentration from J (Jahe), K (Kencur), L (Lengkuas), LG (Lempuyang gajah) dan LP (Lempuyang pahit).Total phenolic concentration were determined by using FolinCiocalteu reagent. Galic acid was used as the reference. The value obtained was the equivalence of miligram of galic acid per gram of extract Gallic Acid Equivalent (GAE).

\section{Radical Scavenging Activity}

Antiradical activity determined by the ability of a compound contained in extract to reduce the purple colour intensity of DPPH radical in its maximum wavelenght (Rohman and Riyanto, 2006). The reduction of purple colour intensity of DPPH radical is caused by the decrease of chromophore or conjugated double bond in DPPH compound. This caused by the existence of extracts compounds which scavenging the radical by donating hydrogen atom to DPPH structure so that become reducted DPPH-H. DPPH-H is a compound which have yellow colour (Huang, et al., 2005).

Based on Reynertson, et al. (2007), a compound can be determined as an active antioxidant if its inhibitory concentration $50 \%$ $\left(\mathrm{IC}_{50}\right)$ value is lower than $50 \mu \mathrm{g} / \mathrm{mL}$. The medium antioxidant activity is determined if the $\mathrm{IC}_{50}$ value of a compound is between $50-100$ $\mu \mathrm{g} / \mathrm{mL}$. The $\mathrm{IC}_{50}$ value between $100-200$ $\mu \mathrm{g} / \mathrm{mL}$ showed that the compound is less active in antioxidant activity, meanwhile $\mathrm{IC}_{50}$ value more than $200 \mu \mathrm{g} / \mathrm{mL}$ showed that the compound is not active as antioxidant.

Table I. The comparison of the antiradical activity of extracts

\begin{tabular}{lcc}
\hline Extract & $\begin{array}{c}\text { Concentration } \\
(\boldsymbol{\mu g} / \mathbf{m L})\end{array}$ & $\begin{array}{c}\text { Antiradical } \\
\text { activity(\%) }\end{array}$ \\
\hline Jahe & 100 & $80.03 \pm 0.593$ \\
Kencur & 100 & $35.58 \pm 4.284$ \\
Lengkuas & 100 & $46.04 \pm 3.531$ \\
Lempuyang gajah & 100 & $38.61 \pm 1.678$ \\
Lempuyang pahit & 100 & $55.31 \pm 5.785$ \\
\hline
\end{tabular}

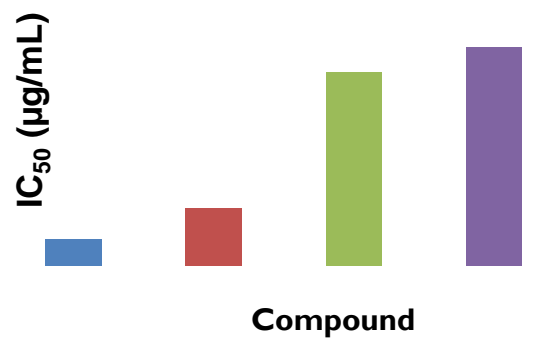

Figure 2. The $I C_{50}$ values of ethanolic extract of Jahe, lengkuas, lempuyang pahit and vitamin $E$. The sampel absorbance were measured by UV-Vis spectrofotometer with $\lambda_{\max } 517.6 \mathrm{~nm}$. 
The parameter used in the interpretation of antiradical activity is the value of $\mathrm{IC}_{50}$. $\mathrm{IC}_{50}$ is the sample concentration having $50 \%$ antiradical activity compared to control which obtained by linier regretion between the concentration versus the percentage of antiradical activity (Rohman and Riyanto, 2006). The results on radical scavenging activity of ethanolic extract of jahe, lengkuas, lempuyang pahit are compared to on radical scavenging activity of vitamin $\mathrm{E}$.

The radical scavenging activity respectively from the lowest to the highest activity are vitamin $\mathrm{E}(12.55 \mu \mathrm{g} / \mathrm{mL})$; extract jahe $(27.38 \mu \mathrm{g} / \mathrm{mL})$; lengkuas $(93.27 \mu \mathrm{g} / \mathrm{mL})$; lempuyang pahit (105.08 $\mu \mathrm{g} / \mathrm{mL}$ ) (Fig. 2).

\section{Correlation between Radical Scavenging Activity and Total Phenolic Concentration}

This study shows that radical scavenging activity $\left(\mathrm{IC}_{50}\right)$ and total phenolic concentration (GAE) of ethanolic extract of jahe (27.38 $\mu \mathrm{g} / \mathrm{mL} ; 73.992 \mathrm{mg} / \mathrm{g}$ ), lengkuas $(93.27 \mu \mathrm{g} / \mathrm{mL}$; $37.841 \mathrm{mg} / \mathrm{g})$, and lempuyang pahit (105.08 $\mu \mathrm{g} / \mathrm{mL} ; 40.802 \mathrm{mg} / \mathrm{g}$ ).

The higher concentration of total phenolic concentration in the extract that means the higher antioxidant activity. The correlation between phenolic concentration and antioxidant activity of the rhizom is known by the correlation coefficient $\left(\mathrm{R}^{2}\right)$ from linier regretion equation between antioxidant activity and total phenolic concentration.
Based on the correlation between total phenolic concentration and the antiradical activity (IC50) by using linier regretion equation is obtained the value of $\mathrm{R}^{2}=0.954$ (Fig. 3). This mean $95.4 \%$ antiradical activities of Zingiberaceae family extracts were donated by phenolic compounds and as many as $4.6 \%$ activities were donated by other compounds. Phenolic compound contained in Zingiberaceae family are gingerol, shogaol, gingeron (Ravindran, et al., 2005), bisdescurcuminoid (Wulandari, 1996), kaempferol (Usia, et al., 2004), flavonoid and non polar constituents such as curcuminoid, kavapiron and gingerol (Sirat, et al, 1996), galangin, kaempferid and pinobanksin flavononol (Hisashi, et al., 2005), 3-O-metil galangin (Tao, et al., 2006).

In the lempuyang gajah and lempuyang pahit are found kaempferol as a flavonol substance that in the 3-O position bind eter and glucoside (Prakash, et al., 2011, Subehan, et al., 2005). Those compound have been known to have antiradical activity (Sirat, et al., 1996) because of their ability in donating the hidrogen atom $(\mathrm{H})$, so that $\mathrm{H}$ could be bind to DPPH radical (hidrazil) to become the neutral form (hidrazin). Beside the phenolic compound, other compounds contained in Zingiberaceae family such as volatile oil, including terpenoid, carotenoid (Habsah, et al., 2000; Mau, et al., 2003; Suhaj, 2006; Chen, et al., 2008), 1'acetoxychavicolasetat (ACA) (Mahae, et al., 2009) are known to have important roles in antiradical activity.

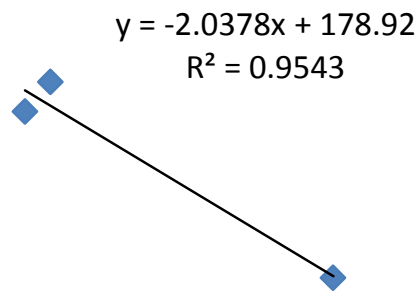

GAE (mg/g)

Figure 2. The correlation of GAE and $\mathbf{I} \mathbf{C}_{\mathbf{5 0}}$. The corelation between phenolic concentration and antioxidant activity of the rhizom is known by the correlation coefficient $\left(R^{2}\right)$ from linier regretion equation between antioxidant activity and total phenolic concentration. The higher concentration of total phenolic concentration in the extract that means the higher antioxidant activity. 
Antiradical activity of Jahe is known to have the highest activity than the other rhizome used in this study $\mathrm{IC}_{50}$ value of jahe $=27.38$ $\mu \mathrm{g} / \mathrm{mL})$. Also the total fenolic concentration of jahe is $73.99 \mathrm{mg} / \mathrm{g}$ and based on Zaeoung, et al. (2004) reported that gingerol compound in jahe is the compound responsible to the antiradical activity, meanwhile the main compound from the extracts used in this study that is responsible in the antiradical activity are not been known yet.

\section{ACKNOWLEDGEMENT}

We would like to thank to Rector of Universitas Muhammadiyah Surakarta for granting of this research through PINPRU program.

\section{REFERENCES}

Abdul, A.B.H., Abdelwahab, S.I., Al-Zubairi, A.S., Elhasan, M.M. and Murali, S.M., 2008, Anticancer and Antimicrobial Activities of Zerumbone from the Rhizomes of Zingiber zerumbut, Int. J. Pharmacol., 4(4), 30 I-304.

Behera, B.C., Adawadkar, B. and Makhija, U., 2004, Capacity of Some Graphidaceous Lichens to Scavenge Superoxide and Inhibition of Tyrosinase and Xanthine Oxidase Activities, Curr. Sci., 87(I), 83-87.

Chen, I.N., Chang, C.C., Ng, C.C., Wang, C.Y., Shyu, Y.T. and Chang, T.L., 2008, Antioxidant and Antimicrobial Activity of Zingiberaceae Plants in Taiwan, Plant Foods Hum. Nutr., 63(I), 15-20.

Chun, K.O., Kim Dae-ok. and Lee, Y.C., 2003, Superoxide Radikal Scavenging Activity of the Major Polyphenol in Fresh Plums, J. Agric. Food Chem., 5 I(27), 8067-8072.

Fessenden, R.J. and Fessenden, J.S., 1986, Organic Chemistry, translated by Pudjaatmakan, A. H., 3rd Edition, Jakarta: Erlangga Publisher.

Habsah, M., Amran, M., Mackeen, M.M., Lajis, N.H., Kikuzaki, H., Nakatani, H., et al., 2000, Screening of Zingiberaceae Extracts for Antimicrobial and Antioxidant Activities, J. Ethnopharmacol., 72, 403-4I0.

Harborne, J. B., 1987, Metode Fitokimia: Penuntun Cara Modern Menganalisis
Tumbuhan, Second Issue, Bandung: ITB Publisher.

Matsuda, H., Ando, S., Kato, T., Morikawa, T. and Yoshikawa, M., 2005, Inhibitors from the Rhizomes of Alpinia officinarumon Production of Nitric Oxide in Lipopolysaccharide-activated Macrophages and the Structural Requirements of diarylheptanoids for the Activity, Bioorg. Med. Chem., I4(I), I38-142.

Huang, D., Ou, B. and Prior, R.L., 2005, The Chemistry behind Antioxidant Capacity Assays, J. Agric. Food Chem., 53(6), I84I-I856.

Khanom, F., Kayahara, H. and Tadasa, K., 2000, Superoxide-Scavenging and Prolyl Endopeptidase Inhibitory Activities of Bangladeshi Indigenous Medicinal Plants, Biosci. Biotechnol. Biochem., 64(4), 837-840.

Kim, D.O., Jeong, S. W. and Lee, C.Y., 2003, Antioxidant Capacity of Phenolic Phytochemicals from Various Cultivars of Plums, Food Chem., 8I(3), 32I326.

Mahae, N. and Chaiseri, S., 2009, Antioxidant Activities and Antioxidative Components in Extracts of Alpiniagalanga (L.) Sw., Kasetsart J. Nat. Sci., 43(2), $358-369$.

Marxen, K., Vanselow, K.H., Lippemeier, S., Hintze, R., Ruser, A. and Hansen, U.P., 2007, Determination of DPPH Radical Oxidation Caused by Methanolic Extract of Some Microalgal Species by Linear Regression Analysis of Spectrophotometric Measurements, Sensors, 7, 2080-2095.

Mau, J.L., Eric, Lai, Y.C., Wang, N.P., Chen, C.C., Chang, C.H., and Chyau, C.C., 2003, Composition and antioxidant activity of the essential oil from Curcuma zedoaria, Food Chem., 82, 583-59l.

Rout, O.P., Acharya, R. and Kumar, M.S., 20II, Zingiber zerumbet (L.) Sm., A Reservoir Plant for Therapeutic Uses: A Review, International Journal of Pharma World Research, 2, 7-8.

Pudjiastuti, B., Dzulkarnain. and Budi, N., 2000, Uji Analgetik Infus Rimpang Lempuyang Pahit (Zingiber americana) pada Mencit Putih, Cermin Dunia Kedokteran, 129. 
Ravindran, P.N. and Babu, K.N., 2005, Ginger The Genus Zingiber, New York: CRC Press.

Reynertson, K.A., 2007, Phytochemical Analysis of Bioactive Constituens from Edible Myrtaceae Fruit, Dissertation, The City University of New York, New York.

Rohman, A., and Riyanto, S., 2006, Aktivitas Antiradikal Bebas Ekstrak Kloroform Buah Mengkudu (Morindacitrifolia, L.) dan Fraksi-fraksinya, Artocarpus, 6(I), 39.

Habib, S.H., Makpol, S., Abdul Hamid, N.A., Das, S., Ngah, W.Z. and Yusof, Y.A., 2008, Ginger Extract (Zingiber officinale) has Anti-cancer and Antiinflammatory Effects on EthionineInduced Hepatoma Rats, Clinics, 63(6), 807-8I3.

Shukla, Y. and Singh, M., 2007, Cancer Preventive Properties of Ginger: A Arief Review, J. Food Chem. Toxicol., 45(5), 683-690.

Sirat, H.M., Rahman, A.A., Itokawa, H. and Morita, H., 1996, Constituents of the Rhizomes of Two Alpinia Species of Malaysia, Planta Med., 62(2), I88-189.

Subehan., Usia, T., Kadota, S. and Tezuka, Y., 2005, Constituents of Zingiber aromaticum and Their CYP3A4 and CYP2D6 Inhibitory Activity, Chem. Pharm. Bull., 53(3), 333-335.

Supinya, T., Yuenyongsawad, S., Sopa, K., and Latthya, A., 2005, Chemical Components and Biological Activities of Volatile oil of Kaempferia galanga Linn, Songklanakarin J. Sci. Technol., 27(Suppl. 2), 503-507.

Surh, Y.J., 2003, Cancer Chemoprevention with Dietary Phytochemical, Nat. Rev. Cancer, 3(I0), 768-780.

Tao, L., Wang, Z.T., Zhu, E.Y., Lu, Y.H. and Wei, D.Z., 2006, HPLC Analysis of Bioactive Flavonoids from the Rhizomeof Alpinia officinarum, S. AFR. J. BOT., 72(I), 163-166.
Tara Shanbhag, V., Chandrakala, S., Sachidananda, A., Kurady, B.L., Smita, S. and Ganesh, S., 2006, Wound Healing Activity of Alcoholic Extract of Kaempferia galangal in Wistar Rats, Indian J. Physiol. Pharmacol., 50(4), 384390.

Teow, C. C., Truong, V. D., Mc. Feeters, Roger F.F., Thompson, R.L., Pecota, K.V., Yencho, G.C., 2007, Antioxidant Activities, Phenolic and B-carotene Contents of Sweet Potato Genotypes with Varying Flesh Colours, Food Chem., I 03(3), 829-838.

Toda, S., Kumura, M. and Ohnishi, M., 199I, Effects of Phenolcarboxylic Acids on Superoxide Anion and Lipid Peroxidation Induced by Superoxide Anion, Planta Med., 57(I), 8-I0.

Tripathy, Y.B. and Upadhyay, A.K., 200I, Antioxidant Property of Mucuana pruriens Linn. Curr., Sci. Bangalore, 80, |377-| 378.

Usia, T., Iwata, H., Hiratsuka, A., Watabe, T., Kadota. S. and Tezuka, Y., 2004, Sesquiterpenes and Flavonol Glycosidesfrom Zingiber aromaticum and Their CYP3A4 and CYP2D6 Inhibitory Activities, J. Nat. Prod., 67(7), I079-I083.

Windono, T., Hendrajaya, K., Nurfatmawati, $\mathrm{H}$. and Soraya F., 200I, Uji Perendaman Radikal Bebas terhadap DPPH Dari Ekstrak Kulit Buah dan Biji Anggur (Vitis liniferol) Probolinggo Biru dan Bali, Artikel hasil penelitian Artocarpus, Vol. I Faculty of Pharmacy UNAIR, Surabaya.

Wulandari, E.T., 1996, Identifikasi Perbedaan Rimpang Lempuyang Pahit, Lempuyang Wangi dan Lempuyang Gajah, Artikel Journal-ilmiah Nasional, Widya Dharma: Majalah Ilmiah Kependidikan.

Sariga, Z., Anuchit, P. and Niwat, K., 2004, Cytotoxic and Free Radical Scavenging Activities of Zingiberaceous rhizomes, Songklanakarin J. Sci. Technol., 27(4), 799-8I2. 